\title{
DPP4 Inhibition in Human Kidney Proximal Tubular Cells - Renoprotection in Diabetic Nephropathy?
}

Usha Panchapakesan*, Simon Gross, Murali Gangadharan Komala, Kate Pegg and Carol A Pollock

Renal Research Group, Kolling Institute of Medical Research, Royal North Shore Hospital, University of Sydney, Australia

\begin{abstract}
Novel diabetic drugs that target the incretin system e.g dipeptidyl peptidase 4 (DPP4) inhibitors have pleiotropic effects other than inhibiting the cleavage of glucagon like peptide 1 (GLP-1). As DPP4 is located at the brush border of the kidney proximal tubular cells (PTC), we hypothesise that it is involved in the processing of luminal peptides influencing the kidney tubulointerstitium in diabetes. Using HK2 cells (human kidney proximal tubular cell line) in order to study the GLP-1 independent effects of DPP4 inhibition on the PTC cells were exposed to high glucose conditions, high mobility protein 1 (HMGB1) and meprin beta. Relevant markers like DPP4, fibronectin, collagen IV, transforming growth factor beta (TGF $\beta$ ), activator protein $1(\mathrm{AP}-1)$ and nuclear factor-kappa B (NF-KB) were measured. We show that linagliptin (DPP4 inhibitor) interferes with the activation of TGF $\beta$ and downstream reduction in fibronectin but not collagen IV expression. Linagliptin reduced HMGB1 but not high glucose induced NF-KB binding. Linagliptin also reduced high glucose induced AP-1 binding. Meprin beta peptides induce AP-1 binding and this was unchanged with linagliptin. Our data provides new insight into the GLP-1 independent role of DPP4 inhibition in kidney PTC exposed to stimuli relevant in diabetic renal complications. Identifying the functionally relevant renal substrates of DPP4 will help us understand and anticipate long term effects on the kidney in patients with diabetes.
\end{abstract}

Keywords: DPP4; Kidney; Proximal tubule; Diabetic nephropathy; Transforming growth factor beta

\section{Introduction}

The incretin system has been the target of newer glucose lowering medications used in the treatment of Type 2 diabetes mellitus. Specific drugs include the glucagon-like peptide 1 (GLP-1) analogues and dipeptidyl peptidase 4 (DPP4) inhibitors. The incretin hormones consist of GLP-1 and gastrointestinal peptide which are released from the gut in response to a meal. GLP-1 promotes insulin release and inhibits glucagon secretion in a glucose dependent manner which results in the regulation of postprandial glucose excursions. Endogenous GLP-1 hormones have a very short half life as they are rapidly degraded by DPP4 where GLP-1 (7-36) amide is cleaved to GLP-1 (9-36) amide, which is the major circulating form. Hence DPP4 inhibitors exert their hypoglycaemic action by raising endogenous levels of GLP-1.

While the main role of DPP4, also known CD26 (EC 3.4.14.5.), is to terminate the action of GLP-1(7-36), it is not exclusively so. DPP4 is a serine exopeptidase belonging to the S9B protein family, members of which cleave $\mathrm{X}$-proline dipeptides from the $\mathrm{N}$-terminus of polypeptides, such as chemokines, neuropeptides, and peptide hormones [1]. It is a $110-\mathrm{kDa}$ type 11 integral membrane glycoprotein and is expressed ubiquitously in most organs and cell types. Importantly, DPP4 is therefore able to cleave a host of other peptides and exert pleiotropic effects independent of GLP-1. Additionally, DPP4 exists as 2 forms (soluble and membrane bound) both of which are capable of proteolytic activity. The soluble form in the circulation is thought to arise from shedding of the membrane forms and is responsible for the glucose lowering effect of the DPP4 inhibitors in clinical use. In contrast, the membrane bound form of DPP4 expressed on the surface of many cell types including kidney tubular cells, endothelial cells and T cells [2] is of major interest with respect to the pleiotropic actions of DPP4.

DPP4 is located on the apical/brush border surface of the kidney proximal tubular cell (PTC) [3], is found in the urine [4] has a high level of expression and activity in the kidney. The proteolytic functions of DPP4 in the kidney have been described using liquid chromatography mass spectrometry based peptidomics, where kidney tissue from
$\mathrm{DPP} 4^{+/+}$( wild type) and DPP4 ${ }^{-/-}$(knockout) mice were compared and this revealed 10 peptides regulated by DPP4 in vivo [5]. Further studies with brush border membranes showed that aminopeptidase activity is required to generate DPP4 substrates [2]. This suggests that DPP4 is involved in the extracellular catabolism of proteins in the kidney, specifically the degradation/catabolism of proline containing peptides [6].

High mobility group box 1 (HMGB1) and meprin beta have been implicated in the pathophysiology of diabetic nephropathy and interestingly have been identified as DPP4 substrates [5,7]. In patients with diabetes, HMGB1 is a proinflammatory cytokine and serum levels have been shown to positively correlate with micro and macroalbuminuria [8]. Meprin $\beta$ gene polymorphisms has been associated with susceptibility to nephropathy in Pima Indians (a group with high incidence of type 2 diabetes and accelerated rate of renal failure) [9]. The level of protein expression and localization of meprin $\beta$ has also been associated with several types of renal pathology such as renal ischemia-reperfusion injury [10], acute renal failure [11] and in diabetic kidneys of $\mathrm{db} / \mathrm{db}$ mice [12]. The physiological relevance of meprin B (homodimers of $\beta$ subunits) has been further investigated by Herzog et al., where purified recombinant meprin $\beta$ was able to process IL-1beta precursor to a biologically active form [13]. This suggests that meprin B has a role in activation of this proinflammatory cytokine. Inhibition of meprin either at a gene or protein level has been shown

*Corresponding author: Usha Panchapakesan, Renal Research Group, Kolling Institute of Medical Research, Royal North Shore Hospital, University of Sydney, St Leonards, NSW 2065 Australia, Tel: 61-2-99264783; Fax: 61-2-99265715; E-mail: usha.panchapakesan@sydney.edu.au

Received June 11, 2013; Accepted June 30, 2013; Published July 05, 2013

Citation: Panchapakesan U, Gross S, Komala MG, Pegg K, Pollock CA (2013) DPP4 Inhibition in Human Kidney Proximal Tubular Cells - Renoprotection in Diabetic Nephropathy? J Diabetes Metab S9: 007. doi:10.4172/2155-6156.S9-007

Copyright: (c) 2013 Panchapakesan U, et al. This is an open-access article distributed under the terms of the Creative Commons Attribution License, which permits unrestricted use, distribution, and reproduction in any medium, provided the original author and source are credited. 
to afford renal protection in various settings. For example, wild type mice were markedly more susceptible to renal injury after ischemia/ reperfusion compared to meprin $\beta$ knockout mice with higher levels of tumour necrosis factor alpha, transforming growth factor beta (TGF $\beta$ ), inducible nitric oxide and heat shock protein 27 [14], which we have previously shown to be unregulated in tubular cells exposed to high glucose [15]. In keeping with this, studies using actinonin (a meprin inhibitor) showed that meprin inhibition was protective in renal hypoxic injury in vitro and in vivo [16]. Apart from the transcription, expression and localisation of meprin as described above, meprin activity was found to be increased in streptozotocin induced diabetic rats [17]. The functional relevance of DPP4 cleaving meprin $\beta$ from 21 41 (substrate) to $25-41$ (product) and what effect it has on the activity is not known and will be investigated in our studies.

We hypothesise that as DPP4 is present on the brush border of the kidney PTC, inhibition of membrane DPP4 is likely to alter the degradation/regulation of peptides in the lumen and thus influence the kidney tubulointerstitium in patients with diabetes mellitus. We chose to conduct our experiments in vitro using HK2 cells (human kidney proximal tubular cell line) in order to investigate the GLP-1 independent effects of DPP4 inhibition on the proximal tubular cell, which is difficult to evaluate in vivo. GLP-1 is secreted by intestinal ileal L cells. Although human kidney proximal tubular cells express the GLP1 receptor, they do not express GLP-1. GLP-1R has been demonstrated at the mRNA level in porcine proximal tubular cell [18] and in human proximal tubular cells (our own unpublished data). With respect to animal models, GLP-1 receptor knockout mice are available however it has been shown that some of the actions of GLP-1(7-36 amide) and its metabolite (9-36 amide) are independent of the GLP-1 receptor [19]. Hence using a GLP-1 receptor knockout model to investigate GLP-1 independent effects of DPP4 inhibition will not fully delineate whether the effects seen are as a result of DPP4 inhibitors raising levels of GLP-1 or independent of this. Hence in vitro studies like ours are necessary to study the direct effects of DPPIV inhibition.

Given that DPP4 cleaves a variety of substrates, we exposed our cells not only to high glucose conditions but also to substrates known to be cleaved by DPP4 and considered to be relevant in diabetic nephropathy, for example HMGB1 and meprin beta. An important aspect of our hypothesis is that signalling pathways which are intracellularly regulated by high glucose will not be affected by DPP4 inhibitors, as DPP4 cleaves extracellular peptides.

\section{Materials and Methods}

\section{Cell culture}

HK2 cells, a primary human proximal tubular cell line (American Type Culture Collection), were grown in Keratinocyte Serum Free Media (KSFM) supplemented with bovine pituitary extract 20-30 $\mu \mathrm{g} /$ $\mathrm{ml}$ and epidermal growth factor 0.1-0.2 ng/ml (Gibco, NY, USA). Cell culture media was changed every 48 hours. These cells were grown at $37^{\circ} \mathrm{C}$ in a humidified $5 \% \mathrm{CO}_{2}$ incubator and were subcultured at $50-80 \%$ confluence using $0.05 \%$ trypsin $0.02 \%$ EDTA (Gibco, NY, USA). The DPP4 inhibitor used in our studies is linagliptin (generously provided by Boehringer-Ingelheim, Germany) is an oral DPP4 inhibitor used clinically to treat patients with Type 2 diabetes mellitus. The endpoint markers in our study include the TGF $\beta$ /profibrotic and inflammatory pathways, both of which are well evidenced in the pathophysiology of diabetic nephropathy.

The IC50 of linagliptin is $1 \mathrm{nM}$ and the final concentration on our cell culture system was $30 \mathrm{nM}$ (as per advice from Boehringer Ingelheim). When $80 \%$ confluent, cells were exposed to $5 \mathrm{mM}$ glucose, $30 \mathrm{mM}$ D-glucose, $30 \mathrm{mM}$ D-glucose plus $30 \mathrm{nM}$ linagliptin for up to $72 \mathrm{~h}$ then harvested. For the TGF $\beta$ experiments, a final concentration of $0.5 \mathrm{nM}$ recombinant human TGF $\beta_{1}$ (R\&D systems, MN, USA) was used instead of glucose. Recombinant high mobility group box protein 1 (ProteinOne, MD, USA) was used at a final concentration of $50 \mathrm{ng} / \mathrm{ml}$. Custom synthesised meprin beta 21-41 and 25-41 were purchased from Auspep Pty. Ltd. and cells were exposed to $1000 \mathrm{ng} /$ $\mathrm{ml}$ final concentration after initial dose finding experiments. For the thrombospondin-1 (TSP-1) experiments, recombinant human TSP1 (R\&D Systems) was used at a concentration of $10 \mathrm{ng} / \mathrm{ml}$ after initial dose finding experiments.

\section{Flow cytometry}

The expression of DPP4 on the surface of HK2 cells was determined with flow cytometry. Cells were exposed to $5 \mathrm{mM}$ and $30 \mathrm{mM}$ glucose for up to 72 hours then harvested and washed with phosphate buffered saline/1\% bovine serum albumin. Equal numbers of cells were incubated with human CD26 (DPP4) - phycoerythrin labeled antibody and isotype control (Miltenyi Biotec Inc, CA, USA). The percentage of cells positive for CD26 (DPP4) was determined using a FACSCalibur standard four colour cytometer (Becton Dickinson, CA, USA).

\section{Western blot analysis}

Cells collected were $95 \%$ confluent and the cell pellet was resuspended in cell lysis buffer containing $50 \mathrm{mM}$ Tris- $\mathrm{HCl}, 150$ $\mathrm{mM} \mathrm{NaCl}, 5 \mathrm{mM}$ EDTA (pH 7.4), 0.5\% Triton-X100, and protease inhibitors (Roche Diagnostics, Mannheim, Germany). Cell lysate was spun at $13000 \mathrm{rpm}$ at $4^{\circ} \mathrm{C}$ for 5 minutes and stored at $-20^{\circ} \mathrm{C}$. Protein quantification (Bio-Rad, CA, USA) was carried out to determine the protein concentration of the cell lysate. 50-80 $\mu \mathrm{g}$ total cell protein was mixed with 6x Laemmli sample buffer containing mercaptoethanol and heated at $95^{\circ} \mathrm{C}$ for 10 minutes. Samples were then analyzed by sodium dodecyl sulfate polyacrylamide gel electrophoresis (SDS-PAGE) using a $10 \%$ gel and electroblotted to Hybond Nitrocellulose membranes (Amersham Pharmacia Biotech, Bucks, UK). Membranes were blocked in Tris-buffered saline containing $0.2 \%$ Tween-20 (TTBS) in $5 \%$ skim milk for 2-3 hours and then incubated overnight at $4^{\circ} \mathrm{C}$ with the following primary antibodies collagen IV 1:5000 (ab6581, Abcam Ltd, Cambridge), fibronectin 1:1000 (Santa Cruz, CA, USA) and phosphorylated smad2 Ser465/467 ( psmad2) 1:500 ( Cell Signaling Technology) in TTBS (Tris Buffered saline with $0.2 \%$ Tween) containing $5 \%$ skim milk. Membranes were washed with TTBS and incubated with horseradish peroxidase conjugated secondary antibody. Proteins were visualized using the enhanced chemiluminescence (ECL) detection system (Amersham Pharmacia Biotech, Bucks, UK). All membranes were reprobed with $\beta$ actin 1:1000 (Santa Cruz, CA, USA) and results were corrected for actin as a loading control and analyzed using Image J software (Java based software program, NIH).

\section{Nuclear extraction and Electrophoretic Mobility Shift Assay (EMSA)}

Nuclear extracts were prepared using NucBuster ${ }^{\mathrm{TM}}$ Protein Extraction Kit (Novagen, Darmstadt, Germany) as per manufacturer's instructions. The DIG Gel Shift Kit (Roche Applied Science, Indianapolis, US), was used in the EMSA. In brief, $25 \mu \mathrm{g}$ of nuclear extract were incubated with $1 \mu \mathrm{g}$ poly [d (I-C)] as the non specific competitor, $1 \mu \mathrm{g}$ poly L-lysine in a binding buffer $(100 \mathrm{mM}$ Hepes, $\mathrm{pH}$ 7.6, $5 \mathrm{mM}$ EDTA, $50 \mathrm{mM}\left(\mathrm{NH}_{4}\right)_{2} \mathrm{SO}_{4}, 5 \mathrm{mM}$ DTT, Tween $20,1 \%$ 
Citation: Panchapakesan U, Gross S, Komala MG, Pegg K, Pollock CA (2013) DPP4 Inhibition in Human Kidney Proximal Tubular Cells Renoprotection in Diabetic Nephropathy? J Diabetes Metab S9: 007. doi:10.4172/2155-6156.S9-007

Page 3 of 8

$\mathrm{w} / \mathrm{v}, 150 \mathrm{mM} \mathrm{KCl})$ and dig-labeled AP-1 (5'-CGC TTG ATG AGT CAG CCG GAA-3') and dig-labeled NF-kB (5'-AGT TGA GGG GAC TTT CCC AGG C-3') consensus oligonucleotide (Promega, WI, USA) for 30 minutes at room temperature. The reaction mixture was electrophoresed through $6 \%$ polyacrylamide gels, transferred onto nylon positively charged membrane (Roche Applied Science, Indianapolis, USA) and then crosslinked using an UV-transilluminator for 3 minutes. The membrane was subjected to immunological detection using anti-Digoxigenin-AP conjugate and chemiluminescence. Results were analyzed using Image J software and shift bands were measured.

\section{TGF $\beta 1$ ELISA}

HK2 cells were treated with $5 \mathrm{mM}$ glucose (control media), $30 \mathrm{mM}$ glucose with and without $30 \mathrm{nM}$ linagliptin for 48 hours. At 48 hours supernatants were collected, spun and stored at $-20^{\circ} \mathrm{C}$ until TGF $\beta 1$ levels were determined with an immunoassay system (Promega, WI, USA) as per manufacturer's instructions and read using a microplate reader at $450 \mathrm{~nm}$. This system is linear between $15.6-1000 \mathrm{pg} / \mathrm{ml}$. Samples were acid treated then neutralized to convert the latent form to the bioactive form of TGF $\beta 1$ in order to measure total TGF $\beta 1$. Active TGF $\beta 1$ was assayed after the supernatants were concentrated using a centrifugal filter unit (Millipore). The assay used was designed to measure biologically active TGF $\beta 1$. Cell lysate protein concentration was determined using Bio-Rad Protein assay and TGF $\beta 1$ levels were corrected for protein content per well.

\section{RNA extraction, reverse transcription and real-time PCR}

RNA was extracted using an RNeasy mini kit (Qiagen, Valencia, CA) according to manufacturer's instructions. RNA was then treated with DNAse and RT-PCR was performed with SuperScriptIII OneStep RT-PCR System and Platinum Taq DNA polymerase (Invitrogen). cDNA was generated by reverse transcribing $1 \mu \mathrm{g}$ of total RNA in a reaction volume of $20 \mu \mathrm{l}$ using VILO cDNA synthesis kits (Invitrogen). One microliter (50 ng) of cDNA was used as a template in a $20 \mu \mathrm{l} \mathrm{PCR}$ reaction. Quantitative real-time PCR was performed using an ABI Prism 7900 HT Sequence Detection System (Applied Biosystems, Foster City, CA) with SYBR Green PCR mastermix. Reactions were performed in at least triplicate and were analyzed by relative quantitation using RQ Manager Software, version 1.2 (Applied Biosystems). The following primers were used for mRNA detection: FN: forward 5'CAAAGCAAAGGCGAGG， reverse 5'-ACGGAGCGAAACTGGC; Actin Forward: 5'- ATCGTGCGTGACATTAAG, Reverse: 5' ATTGCCAATGGTGATGAC.

All data are presented as fold-change compared with control after normalization to actin.

\section{Statistical analysis}

Normalized results are expressed as a percentage of the mean \pm standard error of control values. Experiments were performed at least in triplicate or as detailed in the text with $n$ reflecting the number of separate experiments. Statistical comparisons between groups were made by analysis of variance (ANOVA) or unpaired t-tests where appropriate. Analyses were performed using the software package, Statview version 5.0 (Abacus Concepts Inc., Berkley, CA, USA). P values $<0.05$ considered significant.

\section{Results}

\section{High glucose reduces surface DPP4 expression}

When HK2 cells were exposed to high glucose for up to 72 hours, there was a small but significant down regulation in the expression of surface DPP4 to $88.4 \pm 1.3 \%(\mathrm{n}=4$, $\mathrm{p}$ value $<0.05)$ when measured using flow cytometry at 48 hours however this was not sustained at 72 hours ( Figure 1).

\section{Linagliptin reduces high glucose induced fibronectin expression}

HK2 cells were exposed to high glucose and linagliptin for 24 hours. Here we confirm previous findings that high glucose increases fibronectin expression as well as demonstrate that linagliptin reduces high glucose induced fibronection expression from $132.6 \pm 8.3 \%$ of control to $92.2 \pm 17.8 \%$ of control $(n=4$, $p$ value $<0.05$; Figure $2 a)$.

We further show that linagliptin alone does not have any effect on basal expression of fibronection (Figure $2 b$ ). In this set of data, TGF $\beta$ $(0.5 \mathrm{ng} / \mathrm{ml})$ is used as a positive control.

\section{Linagliptin does not reduce high glucose induced collagen IV expression}

Unlike its effect on high glucose induced fibronectin expression, linagliptin did not reduce the up regulation of collagen IV (CIV) after expression 24 hours ( $n=3$ : Figure 3).

\section{Linagliptin reduces high glucose induced active TGF $\beta 1$ and downstream $p$ smad 2 but not total TGF $\beta 1$ secretion}

HK2 cells exposed to high glucose for 48 hours increased both total (latent and active) and active TGF $\beta 1$ to $157.2 \pm 8.0 \%$ and 397.6 $\pm 29.3 \%$ of control respectively, $(n=3-4$, $p$ value $<0.05$ ). Interestingly linagliptin reduced high glucose induced active, but not total TGF $\beta 1$ secretion to $289.8 \pm 40.4 \%$ ( $\mathrm{p}$ value $<0.05$ ). This is further confirmed with downstream psmad 2 expression as shown in Figure 4a where high glucose induced psmad 2 to $290.7 \pm 64.4 \%$ of control and the addition of linagliptin reduced this to $104.1 \pm 35.2 \%$ of control $(n=4$, both $p$ value $<0.05$ ). This implies linagliptin interferes with the conversion of latent to active TG $\beta 1$. This is shown in Figures $4 a-4 c$.

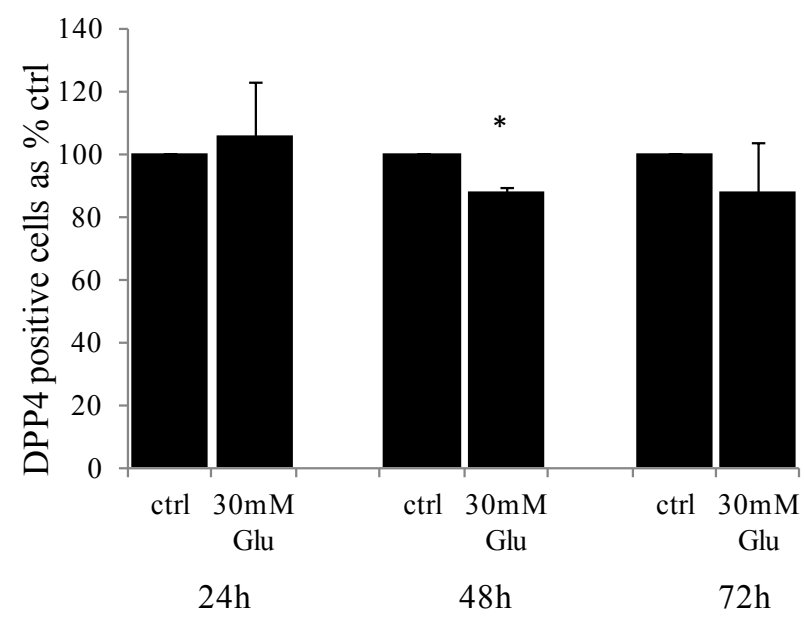

Figure 1: The regulation of surface DPP4 High glucose $(30 \mathrm{mM})$ exposure for $48 \mathrm{~h}$ down regulates DPP4 expression on HK2 cells however there was no change at $24 \mathrm{~h}$ and $72 \mathrm{~h}$. HK2 cells were labeled with DPP4-PE antibody and the percentage of DPP4 positive cells were measured with flow cytometry. $\mathrm{N}=3,{ }^{*} \mathrm{p}<0.05$ 
Citation: Panchapakesan U, Gross S, Komala MG, Pegg K, Pollock CA (2013) DPP4 Inhibition in Human Kidney Proximal Tubular Cells Renoprotection in Diabetic Nephropathy? J Diabetes Metab S9: 007. doi:10.4172/2155-6156.S9-007
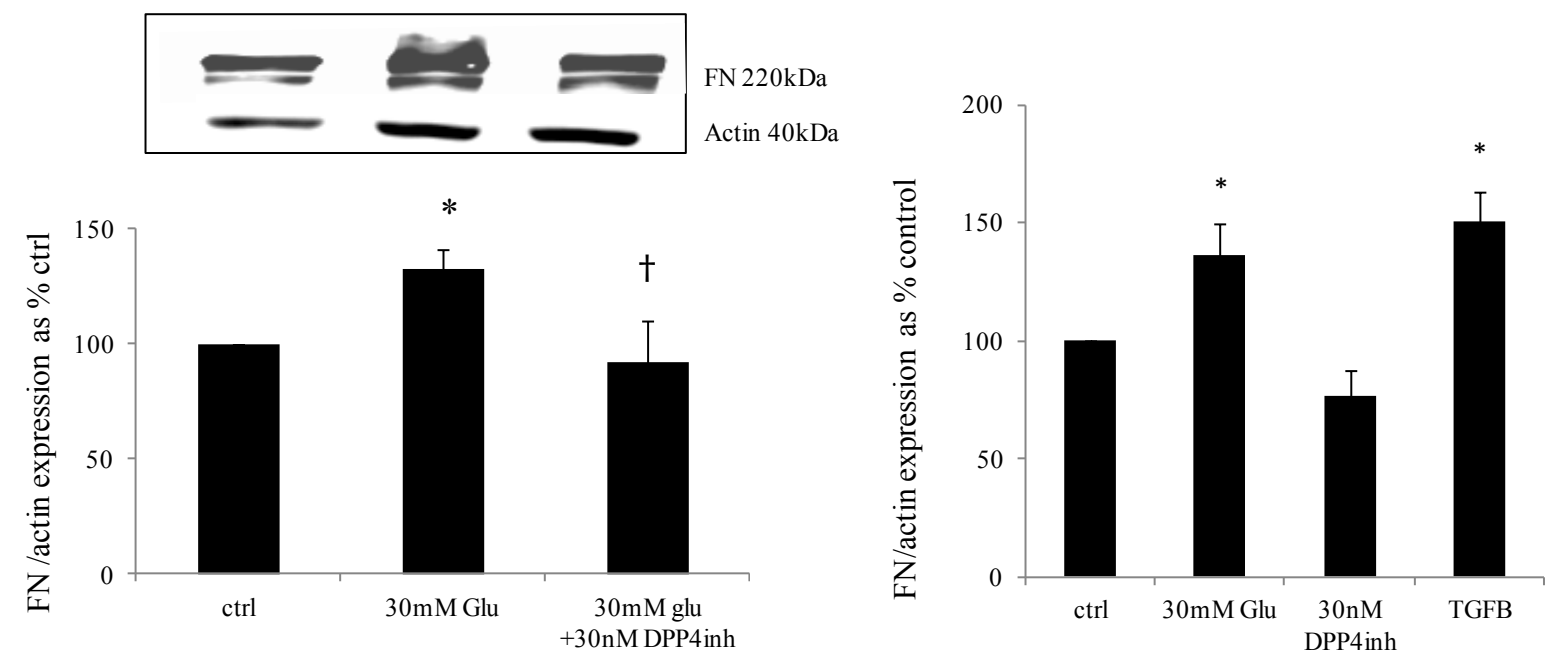

Figure 2: The effect of DPP4 inhibition on fibronectin expression (a) DPP4 inhibition with linagliptin ( $30 \mathrm{nM}$ ) reduced high glucose induced fibronectin expression HK2 cells were treated with high glucose $(30 \mathrm{mM})$ and linagliptin $(30 \mathrm{nM})$ for $24 \mathrm{~h}$. Cell lysate was collected and fibronectin was quantitated using western blot. N=4, * $p<0.05$ vs. ctrl, $\uparrow p<0.05$ vs. $30 \mathrm{mM}$ Glu. (b) DPP4 inhibition with linagliptin alone did not affect basal levels of FN. TGF 1 is used as a positive control. $N=4$, ${ }^{*} p<0.05$ vs. ctrl.
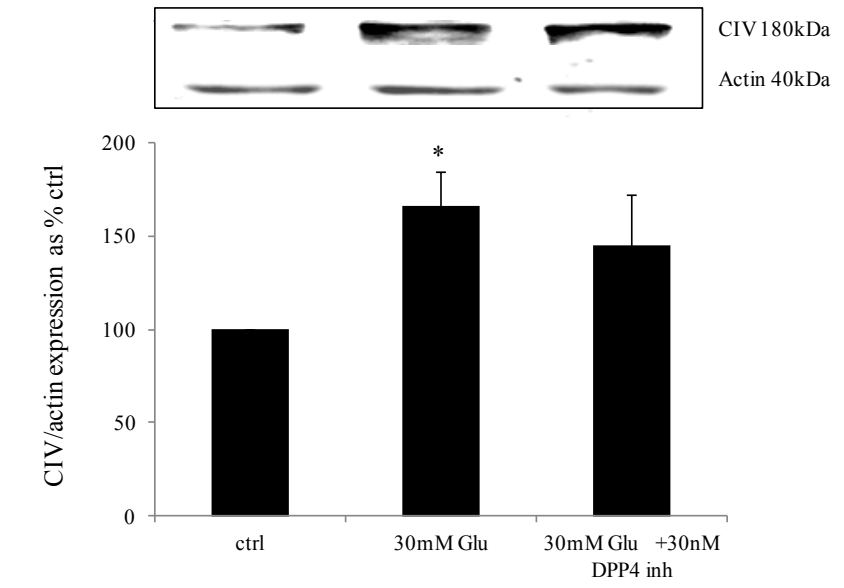

Figure 3: The effect of DPP4 inhibition on collagen IV expression DPP4 inhibition with linagliptin (30 nM) did not reduce high glucose induced collagen IV expression. HK2 cells were treated with high glucose $(30 \mathrm{mM})$ and linagliptin $(30 \mathrm{nM})$ for $24 \mathrm{~h}$. Cell lysate was collected and collagen IV was quantitated using western blot. $\mathrm{N}=3$, ${ }^{*} \mathrm{p}<0.05$ vs. ctrl.

\section{The effect of linagliptin on the conversion of TGF $\beta 1$ is not TSP-1 mediated}

The purpose of these experiments was to investigate the mechanism by which linagliptin interrupts the conversion of latent to active TGF $\beta 1$. We used high glucose to stimulate the production of total TGF $\beta 1$ and hence downstream fibronectin transcription. We demonstrate that linagliptin reduced high glucose induced fibronection transcription from 1.24 fold to 0.97 fold of control values ( $n=6$, $p$ value $<0.05$ ). TSP-1 did not have any further effect on fibronectin in the presence of high glucose. The addition of linagliptin in the presence of TSP-1 and high glucose reduced FN expression to 0.97 fold $(n=5$, $p$ value $<0.05$; Figure $5)$.

\section{Linagliptin reduces high glucose induced AP-1 binding}

HK2 cells exposed to high glucose for 72 hours increased AP-1 binding to $225.7 \pm 5.6 \%$ of control values. Linagliptin reduced this to $139.6 \pm 17.9 \%$ of control values ( $n=3$, p value $<0.05$ Figure 6$)$.

\section{Linagliptin reduces HMGB1 but not high glucose induced NF-kB binding}

Our results demonstrate that the effect of linagliptin on NF- $\mathrm{BB}$ binding is dependent on the type of stimulus used in the system. High glucose increased NF- $\mathrm{kB}$ binding as expected to $130.8 \pm 11.6 \%$ of control values $(n=5)$ and this was not altered with the addition of linagliptin as shown in Figure $7 \mathrm{a}$. High glucose increased secreted HMGB1 to $190.6 \pm 38.0 \%(n=3$; Figure $7 b)$. When HK2 cells were pre-treated with linagliptin for $24 \mathrm{~h}$ prior to stimulation with recombinant HMGB1, NF$\kappa B$ binding was reduced to $38.0 \pm 5.9 \%(n=3$, p value $<0.05$; Figure $7 \mathrm{c}$. To assess whether linagliptin is inhibiting the cleavage of recombinant HMGB1 in our system, we used the same HMGB1 antibody directed to the terminal end of HMGB1 (Ab 67281) as per Marchetti et al. [7] 
Citation: Panchapakesan U, Gross S, Komala MG, Pegg K, Pollock CA (2013) DPP4 Inhibition in Human Kidney Proximal Tubular Cells Renoprotection in Diabetic Nephropathy? J Diabetes Metab S9: 007. doi:10.4172/2155-6156.S9-007

Page 5 of 8
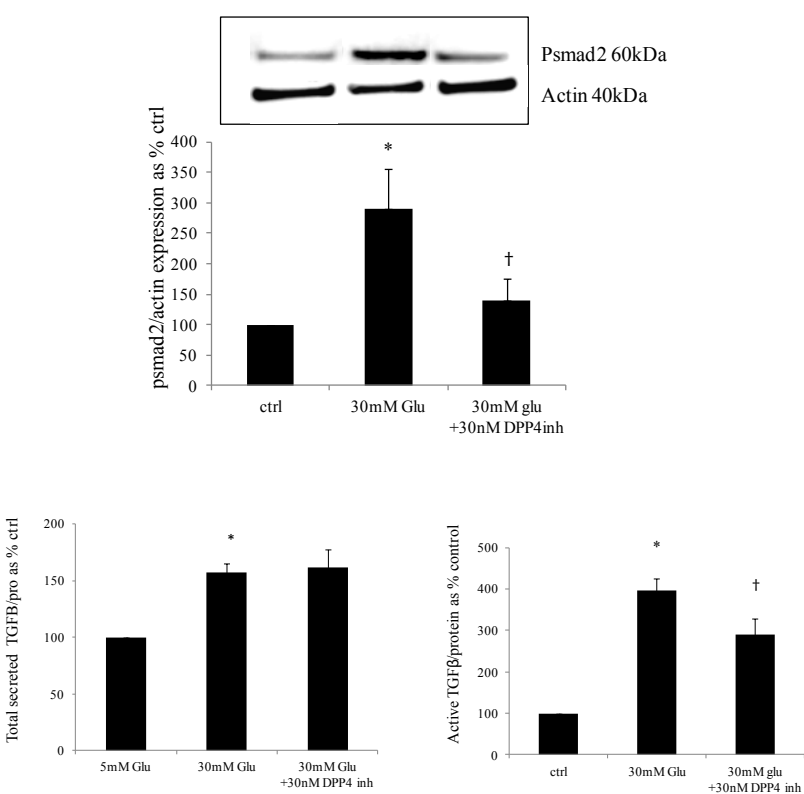

Figure 4: The effect of DPP4 inhibition on TGF $\beta$ and psmad2 expression (a) DPP4 inhibition with linagliptin (30 nM) did not reduce $30 \mathrm{mM}$ high glucose induced total TGF $\beta$ secretion. HK2 cells were treated with high glucose $(30 \mathrm{mM})$ and linagliptin $(30 \mathrm{nM})$ for $48 \mathrm{~h}$. Supernatant was collected and total TGFB was determined using ELISA. $N=4,{ }^{*} p<0.05$ vs. ctrl. (b) DPP4 inhibition with linagliptin $(30 \mathrm{nM})$ reduced $30 \mathrm{mM}$ high glucose induced active TGF $\beta$ secretion. HK2 cells were treated with high glucose $(30 \mathrm{mM})$ and linagliptin $(30 \mathrm{nM})$ for $48 \mathrm{~h}$. Supernatant was collected and total TGFB was determined using ELISA. $\mathrm{N}=3,{ }^{*} \mathrm{p}<0.05$ vs. ctrl and $\dagger \mathrm{p}<0.05$ vs. $30 \mathrm{mM}$ Glu. (c) DPP4 inhibition with linagliptin $(30 \mathrm{nM})$ reduced $30 \mathrm{mM}$ high glucose induced psmad2 expression. HK2 cells were treated with high glucose $(30 \mathrm{mM})$ and linagliptin $(30 \mathrm{nM})$ for 48 h. Cell lysate was collected and psmad2 expression corrected for actin was determined using western blot. $N=4,{ }^{*} p<0.05$ vs. ctrl and $+p<0.05$ vs. $30 \mathrm{mM}$ Glu.

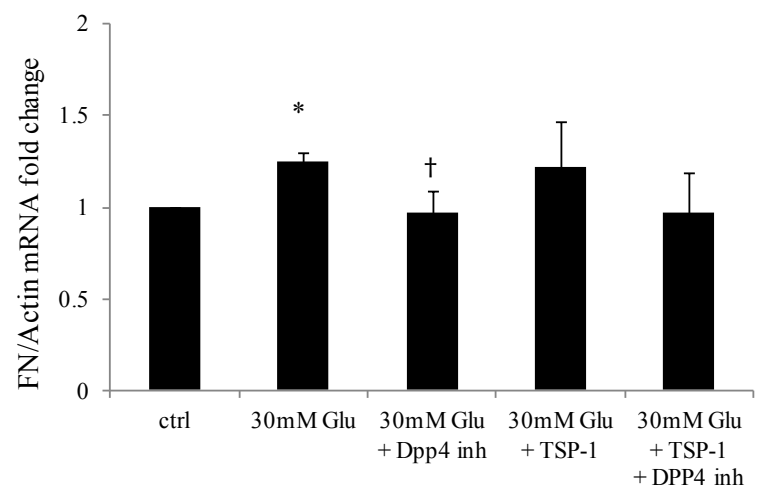

Figure 5: The effect of linagliptin on FN transcription is not TSP-1 mediated Linagliptin reduced high glucose induced FN mRNA transcription. Recombinant TSP-1 did not have any additional effects when added to $30 \mathrm{mM}$ glucose. In the presence of excess recombinant TSP-1, linagliptin was still able to suppress FN. $N=5,{ }^{\star} p<0.05$ vs. ctrl, $\uparrow p<0.05$ vs. $30 \mathrm{mM}$ Glu.

and this showed no change. These results are represented in Figure $7 \mathrm{~d}$.

Both meprin beta peptides induce AP-1 binding and this is unchanged with linagliptin

Meprin beta 21-41 (DPP4 substrate) and 25-41 (product) were added to HK2 cells for 24 hours and both peptides were able to increase
AP-1 binding. The addition of linagliptin (to inhibit the cleavage of meprin 21-41 to 25-41) did not differ significantly compared to meprin 21-41 alone (Figure 8).

\section{Discussion}

In our studies, although high glucose reduced surface expression of DPP4 at 48 hours, this was not sustained at 72 hours. Other groups have postulated that shedding of DPP 4 from the cell membrane surface occurs as a response to injury. It is known that other factors such as insulin and tumour necrosis factor $\alpha$ as well as certain cancers also promote shedding of surface DPP4 [20,21].

Targeting the TGF $\beta$ pathway is a major therapeutic goal in ameliorating fibrosis in diabetic nephropathy. There are very few studies investigating the direct non GLP-1 effect of DPP4 inhibition on the TGF $\beta$ pathway. Inhibitors of DPP4 like activity were able to abrogate the TGF $\beta 1$-induced stimulation of collagen synthesis, matrix deposition, and TGF $\beta 1$ (1) and fibronectin [22] in skin fibroblasts. In the kidney, TGF $\beta$ is secreted in a latent form and requires a complex interplay of soluble signalling molecules in the activation process which releases it from the latency associated peptide (LAP). Once released from the LAP, the unbound TGF $\beta$ can then bind to its receptor to initiate cell signalling via smad2/3 pathway. Several other molecules such as plasminogen, thrombospondin- 1 and mannose 6 phosphate receptor (M6PR) participate in this activation process. We have shown that high glucose increases both total and active TGF $\beta$ however linagliptin only reduced active but not total TGF $\beta$ levels in the supernatant. This implies that there is an interruption in the conversion of total to active TGF $\beta 1$. The reduction in active TGF $\beta 1$ levels translated to a downstream effect of reduced phosphorylated smad2 expression and the extracellular matrix protein fibronectin, both at a transcriptional and protein level. This suggests that linagliptin is reducing fibronection through a TGF $\beta$ dependent mechanism. As we are using an in vitro cell culture system devoid of GLP-1 and plasminogen, the mechanism by which linagliptin interferes with the conversion of TGF $\beta 1$ is unlikely to involve these molecules. Several groups have shown that thrombospondin (TSP-1) is

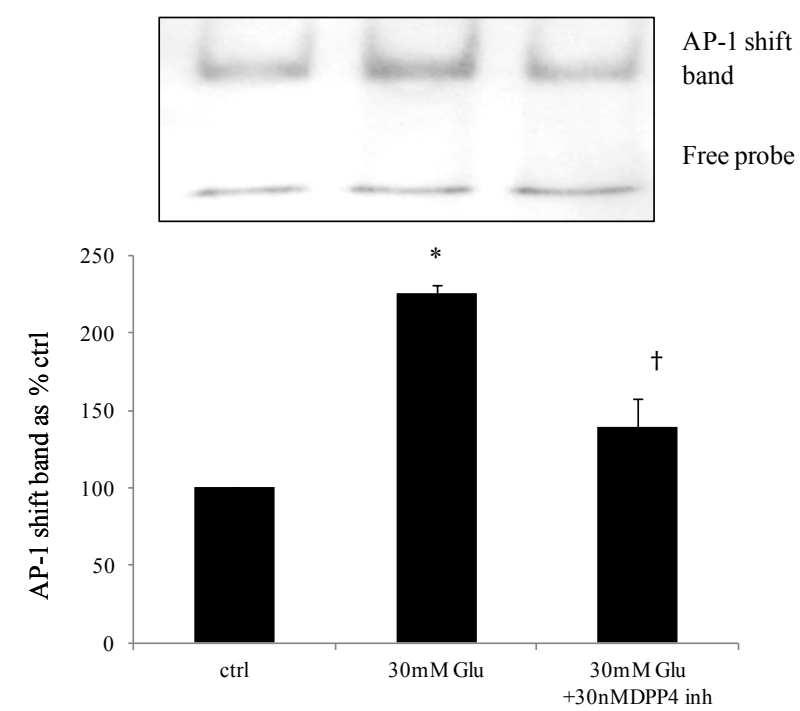

Figure 6: The effect of DPP4 inhibition on AP-1 binding DPP4 inhibition with linagliptin $(30 \mathrm{nM})$ reduced high glucose induced AP-1 binding. HK2 cells were treated with high glucose $(30 \mathrm{mM})$ and linagliptin $(30 \mathrm{nM})$ for $72 \mathrm{~h}$. Nuclear extract was collected and AP-1 was quantitated using EMSA. $\mathrm{N}=3,{ }^{*} \mathrm{p}<0.05$ vs. ctrl, $\uparrow p<0.05$ vs. $30 \mathrm{mM}$ Glu. 

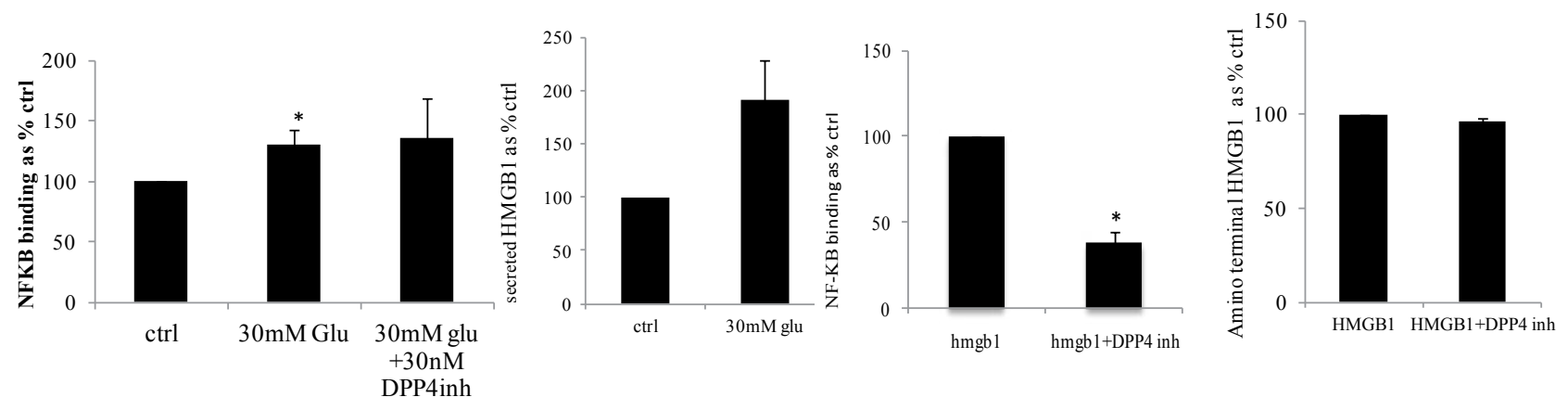

Figure 7: The effect of DPP4 inhibition on NF-KB binding (a) High glucose increased NF-KB binding and this was not reduced by the addition of linagliptin. (b) High glucose increased secreted HMGB1 after 24 hours. HMGB1 in the cell culture supernatant was quantitated using western blot. (c) DPP4 inhibition with linagliptin (30 $\mathrm{nM})$ reduced recombinant HMGB1 (50 nM) induced NF-KB binding. HK2 cells were exposed to recombinant HMGB1 for 2 hours after $24 \mathrm{~h}$ pretreatment with linagliptin. $\mathrm{NF}-\mathrm{KB}$ binding was measured with eletrophoretic mobility shift assay. $\mathrm{N}=3$, ${ }^{*} \mathrm{p}<0.05$ vs. ctrl/HMGB1. (d) Recombinant HMGB1 was not altered by pretreatment with linagliptin ( $30 \mathrm{nM})$ in HK2 cells. The antibody used to probe the western blot was directed to the amino terminal end of HMGB1 and should detect cleavage of HMGB1.

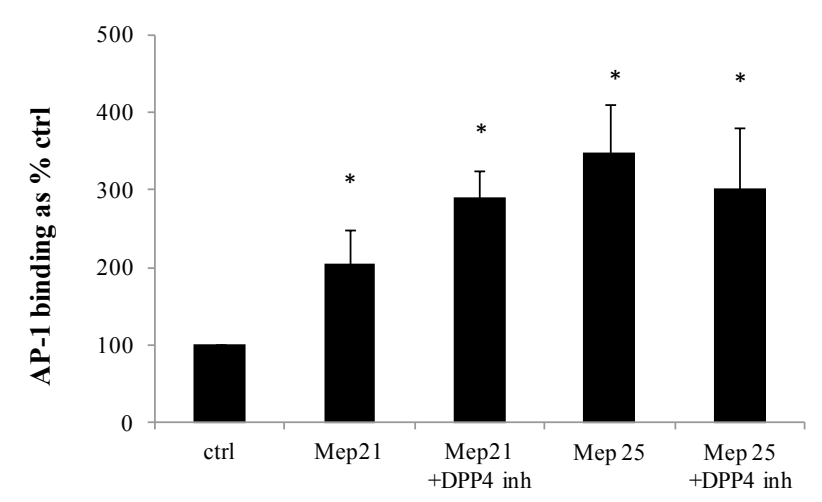

Figure 8: The effect of meprin beta peptides and DPP4 inhibition on AP-1 binding Both meprin 21- 41 and meprin 25-41 increased AP-1 binding. The addition of linagliptin did not alter the levels. Nuclear extract was collected and AP-1 was quantitated using EMSA. $N=5$, ${ }^{*} p<0.05$ vs. ctrl.

involved in the renal activation of TGF $\beta 1[23,24]$ hence the next logical step was to investigate the effect of linagliptin on TSP-1. Given that the suppressive effects of linagliptin were not overcome by an excess of TSP-1 in our experiments, this would suggest that linagliptin is not interfering in the activation of TGF $\beta 1$ through TSP-1.

Collagen IV (CIV) accumulation in the basement membrane of PTCs is one of the earliest changes in the diabetic kidney. In our studies, high glucose induced CIV expression was not reduced by linagliptin. This was an expected finding as high glucose can regulate CIV through the polyol pathway and directly stimulate gene expression $[25,26]$ independently of TGF $\beta 1$. The polyol pathway is activated in cells such as PTCs where glucose entry is independent of insulin. So, this finding is in keeping with our hypothesis that DPP4 inhibition is more likely to alter extracellular mediators but not the intracellular regulation induced by hyperglycaemia.

The role of DPP4 in modifying inflammation seems variable. On the one hand there is a negative correlation between the expression and activity of DPP4 with neurogenic inflammation [27], airway inflammation [28] and arthritis [29]. However there are also reports that the DPP4 inhibition exerts antiatherosclerotic effects and reduces inflammation via inhibition of monocyte activation/chemotaxis in male LDLR (-/-) mice [30]; reduce local inflammation in adipose tissue and pancreatic islets of obese mice [31] and reduced inflammation as well as accelerated epithelialisation of wounds in diabetic $o b / o b$ mice [32]. It is important to note that DPP4 inhibition raises GLP-1 levels in in vivo models so it is difficult to differentiate whether the effects seen are as a result of raised GLP-1 levels or direct effects of DPP4 inhibition independent of GLP-1.

In our studies we saw quite divergent effects of linagliptin on 2 major transcription factors relevant to diabetic nephropathy. Transcription factors are proteins that bind to promoter regions of target genes and regulate their transcription. Both NF- $\mathrm{kB}$ and $\mathrm{AP}-1$ are key transcription factors mediating the fibrotic and inflammatory pathways in HK2 cells exposed to high glucose $[33,34]$. There was marked suppression of high glucose induced AP-1 binding, the mechanism of which is unclear. Linagliptin did not alter high glucose induced NF- $\kappa \mathrm{B}$ binding but had significant effects when HMGB1 was used as a stimulus. Furthermore, we showed that mechanistically this was not related to cleaving HMGB1. The difference in NF- $\mathrm{kB}$ binding seen is likely due to glucose entering the kidney PTC cells via the sodium glucose cotransporter 2 and causing intracellular effects whereas HMGB1 is an extracellular ligand of membrane bound toll like receptor 2 and 4 as well as the receptor for advanced glycation end products ( RAGE) and so is exposed to DPP4. 
Citation: Panchapakesan U, Gross S, Komala MG, Pegg K, Pollock CA (2013) DPP4 Inhibition in Human Kidney Proximal Tubular Cells Renoprotection in Diabetic Nephropathy? J Diabetes Metab S9: 007. doi:10.4172/2155-6156.S9-007

As discussed earlier, meprin beta is implicated in the development of diabetic nephropathy. Given that proteomics studies have identified meprin beta $21-41$ as a substrate of DPP4 (cleaved to meprin beta 25-41), it would be logical to investigate the functional relevance of linagliptin on meprin beta in vitro. Both peptides caused an increase in AP-1 binding and the addition of linagliptin did not significantly alter this (in contrast to high glucose induced AP-1 binding). As both the substrate and product cause AP-1 binding, it would be expected that inhibiting the cleavage of meprin 21-41 would not have significant differences in our system.

DPP4 is a multifunctional protein and its function varies according to its location/cell type and availability or concentration of substrates [35]. For example, the physiological and clinical relevance of non GLP1 substrates is highlighted by the commonly seen adverse effects of DPP4 inhibitors such as rhinitis and sinus congestion which is thought to occur because the loss of DPP4 activity contributes to the neurogenic inflammation induced by substance $\mathrm{P}$ in the nasal mucosa [27]. Although peptidomics have aided the identification of DPP4 substrates in the kidney, further studies delineating the functional relevance of this is lacking.

The varied biological role of DPP4 in many physiological processes is to be expected and our results presented here support this notion. Although linagliptin interrupts the TGF $\beta 1$ pathway, its effect on inflammatory mediators seem variable. Our data provides new insight into the GLP-1 independent role of DPP4 inhibition in kidney proximal tubular cells exposed to stimuli relevant in diabetic renal complications. Identifying the functionally relevant renal substrates of DPP4 will help us understand and anticipate long term effects of DPP4 inhibition on the kidney in patients with diabetes. This is important as trials have shown that although diabetic drugs improve glycaemic control, they are not always associated with protective renal outcomes. Defining hypoglycaemic agents that preserve kidney function in patients with diabetes will reduce the socioeconomic and personal burden of the increasingly common diagnosis of diabetes.

\section{Acknowledgement} funding

We would like to thank Boehringer Ingelheim for providing the linagliptin and

\section{References}

1. Ansorge S, Nordhoff K, Bank U, Heimburg A, Julius H, et al. (2011) Novel aspects of cellular action of dipeptidyl peptidase IV/CD26. Biol Chem 392: 153168

2. Lone AM, Nolte WM, Tinoco AD, Saghatelian A (2010) Peptidomics of the prolyl peptidases. AAPS J 12: 483-491.

3. Mentlein R (1999) Dipeptidyl-peptidase IV (CD26)--role in the inactivation of regulatory peptides. Regul Pept 85: 9-24.

4. Stiller D, Bahn H, August C (1991) Demonstration of glomerular DPP IV activity in kidney diseases. Acta Histochem 91: 105-109.

5. Tagore DM, Nolte WM, Neveu JM, Rangel R, Guzman-Rojas L, et al. (2009) Peptidase substrates via global peptide profiling. Nat Chem Biol 5: 23-25.

6. Tiruppathi C, Miyamoto Y, Ganapathy V, Roesel RA, Whitford GM, et al. (1990) Hydrolysis and transport of proline-containing peptides in renal brushborder membrane vesicles from dipeptidyl peptidase IV-positive and dipeptidy peptidase IV-negative rat strains. J Biol Chem 265: 1476-1483.

7. Marchetti C, Di Carlo A, Facchiano F, Senatore C, De Cristofaro R, et al (2012) High mobility group box 1 is a novel substrate of dipeptidyl peptidaseIV. Diabetologia 55: 236-244.

8. Nin JW, Ferreira I, Schalkwijk CG, Prins MH, Chaturvedi N, et al. (2012) Serum high-mobility group box-1 levels are positively associated with micro- and macroalbuminuria but not with cardiovascular disease in type 1 diabetes: the EURODIAB Prospective Complications Study. Eur J Endocrinol 166: 325-332.
9. Red Eagle AR, Hanson RL, Jiang W, Han X, Matters GL, et al. (2005) Meprin beta metalloprotease gene polymorphisms associated with diabetic nephropathy in the Pima Indians. Hum Genet 118: 12-22.

10. Walker PD, Kaushal GP, Shah SV (1998) Meprin A, the major matrix degrading enzyme in renal tubules, produces a novel nidogen fragment in vitro and in vivo. Kidney Int 53: 1673-1680.

11. Trachtman H, Valderrama E, Dietrich JM, Bond JS (1995) The role of meprin $A$ in the pathogenesis of acute renal failure. Biochem Biophys Res Commun 208: 498-505.

12. Mathew R, Futterweit S, Valderrama E, Tarectecan AA, Bylander JE, et al (2005) Meprin-alpha in chronic diabetic nephropathy: interaction with the reninangiotensin axis. Am J Physiol Renal Physiol 289: F911-921.

13. Herzog C, Kaushal GP, Haun RS (2005) Generation of biologically active interleukin-1 beta by meprin B. Cytokine 31: 394-403.

14. Bylander J, Li Q, Ramesh G, Zhang B, Reeves WB, et al. (2008) Targeted disruption of the meprin metalloproteinase beta gene protects against renal ischemia-reperfusion injury in mice. Am J Physiol Renal Physiol 294: F480-490.

15. Qi W, Chen X, Gilbert RE, Zhang Y, Waltham M, et al. (2007) High glucoseinduced thioredoxin-interacting protein in renal proximal tubule cells is independent of transforming growth factor-beta1. Am J Pathol 171: 744-754.

16. Carmago S, Shah SV, Walker PD (2002) Meprin, a brush-border enzyme, plays an important role in hypoxic/ischemic acute renal tubular injury in rats. Kidney Int 61: 959-966.

17. Trachtman H, Greenwald R, Moak S, Tang J, Bond JS (1993) Meprin activity in rats with experimental renal disease. Life Sci 53: 1339-1344.

18. Schlatter P, Beglinger C, Drewe J, Gutmann H (2007) Glucagon-like peptide receptor expression in primary porcine proximal tubular cells. Regul Pept 141: 120-128.

19. Heo KS, Fujiwara K, Abe J (2012) Glucagon-like peptide-1 and its cardiovascular effects. Curr Atheroscler Rep 14: 422-428.

20. Lamers D, Famulla S, Wronkowitz N, Hartwig S, Lehr S, et al. (2011) Dipeptidy peptidase 4 is a novel adipokine potentially linking obesity to the metabolic syndrome. Diabetes 60: 1917-1925.

21. Cordero OJ, Salgado FJ, Nogueira M (2009) On the origin of serum CD26 and its altered concentration in cancer patients. Cancer Immunol Immunother 58: 1723-1747.

22. Thielitz A, Vetter RW, Schultze B, Wrenger S, Simeoni L, et al. (2008) Inhibitors of dipeptidyl peptidase IV-like activity mediate antifibrotic effects in normal and keloid-derived skin fibroblasts. J Invest Dermatol 128: 855-866.

23. Lu A, Miao M, Schoeb TR, Agarwal A, Murphy-Ullrich JE (2011) Blockade of TSP1-dependent TGF- $\hat{\mid}^{2}$ activity reduces renal injury and proteinuria in a murine model of diabetic nephropathy. Am J Pathol 178: 2573-2586.

24. Hugo C, Daniel C (2009) Thrombospondin in renal disease. Nephron Exp Nephrol 111: e61-66.

25. Bleyer AJ, Fumo P, Snipes ER, Goldfarb S, Simmons DA, et al. (1994) Polyo pathway mediates high glucose-induced collagen synthesis in proximal tubule. Kidney Int 45: 659-666.

26. Ziyadeh FN (1993) Renal tubular basement membrane and collagen type IV in diabetes mellitus. Kidney Int 43: 114-120.

27. Grouzmann E, Monod M, Landis B, Wilk S, Brakch N, et al. (2002) Loss of dipeptidylpeptidase IV activity in chronic rhinosinusitis contributes to the neurogenic inflammation induced by substance $P$ in the nasal mucosa. FASEB J 16: 1132-1134

28. Landis BN, Grouzmann E, Monod M, Busso N, Petak F, et al. (2008) Implication of dipeptidylpeptidase IV activity in human bronchial inflammation and in bronchoconstriction evaluated in anesthetized rabbits. Respiration 75: 89-97.

29. Busso N, Wagtmann N, Herling C, Chobaz-Péclat V, Bischof-Delaloye A, et al (2005) Circulating CD26 is negatively associated with inflammation in human and experimental arthritis. Am J Pathol 166: 433-442.

30. Shah Z, Kampfrath T, Deiuliis JA, Zhong J, Pineda C, et al. (2011) Long-term dipeptidyl-peptidase 4 inhibition reduces atherosclerosis and inflammation via effects on monocyte recruitment and chemotaxis. Circulation 124: 2338-2349. 
Citation: Panchapakesan U, Gross S, Komala MG, Pegg K, Pollock CA (2013) DPP4 Inhibition in Human Kidney Proximal Tubular Cells Renoprotection in Diabetic Nephropathy? J Diabetes Metab S9: 007. doi:10.4172/2155-6156.S9-007

31. Dobrian AD, Ma Q, Lindsay JW, Leone KA, Ma K, et al. (2011) Dipeptidyl peptidase IV inhibitor sitagliptin reduces local inflammation in adipose tissue and in pancreatic islets of obese mice. Am J Physiol Endocrinol Metab 300: E410-421.

32. Schürmann C, Linke A, Engelmann-Pilger K, Steinmetz C, Mark M, et al. (2012) The dipeptidyl peptidase-4 inhibitor linagliptin attenuates inflammation and accelerates epithelialization in wounds of diabetic ob/ob mice. J Pharmacol Exp Ther 342: 71-80
33. Panchapakesan U, Pollock CA, Chen XM (2004) The effect of high glucose and PPAR-gamma agonists on PPAR-gamma expression and function in HK-2 cells. Am J Physiol Renal Physiol 287: F528-534.

34. Panchapakesan U, Sumual S, Pollock CA, Chen X (2005) PPARgamma agonists exert antifibrotic effects in renal tubular cells exposed to high glucose. Am J Physiol Renal Physiol 289: F1153-1158.

35. Boonacker E, Van Noorden CJ (2003) The multifunctional or moonlighting protein CD26/DPPIV. Eur J Cell Biol 82: 53-73. 